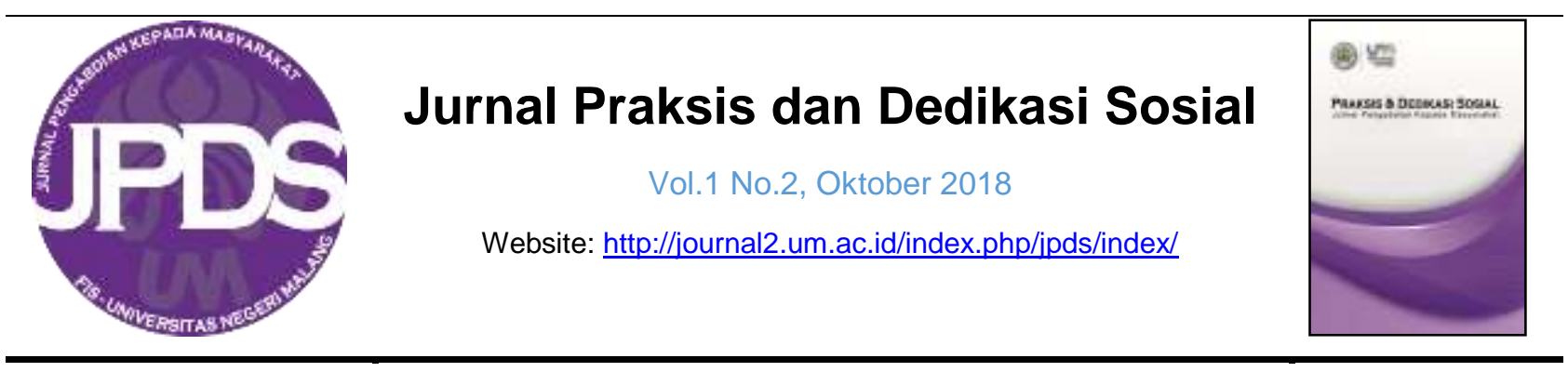

\title{
INSERVICE GURU MGMP IPS SMP KABUPATEN BLITAR DALAM PEMBELAJARAN PETA NKRI
}

I Nyoman Ruja ${ }^{1}$, Neni Wahyuningtyas ${ }^{2}$

${ }^{1,2}$ Program Studi Pendidikan IPS, Fakultas IImu Sosial, Universitas Negeri Malang.

Diterima 10 Mei 2018, dipublikasikan 31 Oktober 2018.

\begin{abstract}
Abstrak
Guru-guru IPS SMP kesulitan untuk mempelajari secara mandiri konsep Sejarah, Geografi, Sosiologi, Ekonomi yang ada pada buku-buku SMP, SMU, dan PT. Selain itu adanya miskonsepsi materi sosiologi dalam buku-buku yang dipergunakan guru sebagai buku pegangan dalam proses belajar mengajar. Miskonsepsi pada buku akan menimbulkan dampak negatif bagi para pengguna (guru dan siswa). Sehingga guru harus selektif dalam memilih buku yang digunakan dalam proses belajar mengajar (PBM). Kemampuan guru untuk menyeleksi buku berkaitan langsung dengan kompetensi guru dalam penguasaan materi pelajaran. Hal ini tidaklah mudah karena seorang guru harus menguasai seluruh materi yang diajarkan. Pada kegiatan pengabdian masyarakat kali ini, guru akan diajak melakukan diskusi untuk pendalaman konsep materi terutama Geografi, menemukan miskonsepsi atau kesalahan konsep materi bentuk muka bumi pada buku IPS SMP yang digunakan dalam pembelajaran, mengintegrasi materi geografi dengan materi IPS lainnya supaya lebih terpadu. Selanjutntya akan dilakukan tutorial untuk mengoreksi kesalahan-kesalahan konsep yang ditemukan. Melalui pengabdian ini telah meningkatkan motivasi dan pemahaman guru-guru matapelajaran IPS yang tergabung dalam MGMP IPS di Kabupaten Blitar terutama tentang materi Geografi (peta NKRI).
\end{abstract}

\section{Kata Kunci}

Inservice, pembelajaran IPS, NKRI

(C) 2018 Penulis

\section{PENDAHULUAN}

Persolan guru di Indonesia pada saat ini seringkali terkait dengan masalah-masalah kualifikasi yang rendah, pembinaan yang terpusat, perlindungan profesi yang belum memadai, persebaran yang tidak merata, guru mengajar tidak sesuai dengan latar

\footnotetext{
${ }^{1}$ Surel Korespondensi: ruja.nyoman.fis@um.ac.id
}

belakang bidang keahliannya, dan lain sebagainya.Segala persoalan guru tersebut timbul oleh berbagai sebab dan masingmasing saling mempengaruhi.

Sumber permasalahan pendidikan yang terbesar sebenarnya adalah adanya perubahan, karena itu permasalahan akan senantiasa ada sampai kapanpun. Situasi pendidikan dituntut untuk menyesuaikan 
dengan perubahan perkembangan yang ada dalam masyarakat, demikian pula dengan guru yang senantiasa dituntut untuk menyesuaikan dengan perubahan.Akibatnya demikian banyak permasalahan yang dihadapi guru, karena ketidakmampuannya menyesuaikan dengan perubahan yang terjadi disekelilingnya karena keterbatasan sebagai individu atau karena keterbatasan kemampuan sekolah dan pemerintah.Jadi masalah pendidikan senantiasa muncul karena adanya tuntutan agar instintusi pendidikan termasuk guru menyesuaikan dengan segala perkembangan yang ada dalam masyarakat.

Permasalahan mendasar bagi guru mata pelajaran IPS antara lain adalah guru mata pelajaran IPS masih belum sepenuhnya bisa melaksanakan sesuai dengan apa yang diamanatkan struktur dan isi kurikulum 2013 dimana materi IPS disajikan terpadu, tidak dipisah dalam kelompok Geografi, Sejarah, Ekonomi, Sosiologi, menggunakan Geografi sebagai platform kajian dengan pertimbangan semua kejadian dan kegiatan terikat dengan lokasi, diajarkan oleh satu orang guru yang memberikan wawasan terpadu antar mata kajian tersebut. Kenyataan yang terjadi di lapangan saat ini banyak pengampu IPS, bukan dari lulusan sarjana Pendidikan IPS, sehingga mereka kesulitan untuk mengintegrasikan IPS secara terpadu. Selain hal tersebut kesulitan lain yang dihadapi guru adalah ketika seorang guru dari latar belakang pendidikan keilmuan yang terpisah misalnya dari latar belakang Geografi dituntut untuk mengajarkan materi Sosiologi, Ekonomi, Sejarah secara terpadu.
Sesuai dengan Permen No 16 Tahun 2007 tentang Kompetensi Guru, terutama tentang kompetensi profesional dijelaskan bahwa seorang guru dituntut untuk menguasai materi, struktur, konsep, dan pola pikir keilmuan yang mendukung mata pelajaran; menguasai $\mathrm{KI}$ dan $\mathrm{KD}$, mengembangkan materi pembelajaran secara kreatif; mengembangkan keprofesionalan secara berkelanjutan dengan melakukan tindakan reflektif, dan memanfaatkan TIK untuk mengembangkan diri. Dengan demikian, seorang guru IPS harus menguasai seluruh materi yang diajarkan (Geografi, Sejarah, Ekonomi, dan Sosiologi secara terpadu).

Beberapa cara yang dapat ditempuh dalam pengembangan profesional guru terutama dalam menguasai materi, struktur, konsep, dan pola pikir keilmuan yang mendukung mata pelajaran, antara lain melalui pembinaan, pendidikan pra jabatan, dan pendidikan dalam jabatan yang dapat berupa supervisi (bantuan/pembinaan) secara teratur dari kepala sekolah dengan tujuan meningkatkan profesional guru sehingga mutu situasi belajar mengajar dapat ditingkatkan. Upaya pengembangan kompetensi guru juga diperkuat oleh adanya UU No. 14 Tahun 2005 tentang Guru dan Dosen sebagaimana tercantum dalam Pasal 34 tentang pembinaan dan pengembangan dimana pengembangan kompetensi guru tersebut merupakan hal yang wajib dilakukan baik oleh pemerintah maupun pemerintah daerah pada satuan pendidikan yang diselenggarakan oleh pemerintah, pemerintah daerah, atau masyarakat. 


\section{Nyoman Ruja \& Neni Wahyuningtyas}

Menurut Ibrohim (2000) beberapa alternatif untuk menanggulangi adanya miskonsepsi antara lain adalah (a) perlu adanya suatu forum untuk selalu mendapatkan pengayaan materi-materi sesuai dengan perkembangan ilmu pengetahuan dan teknologi, (b) perlu adanya suatu bentuk program pengabdian oleh PT untuk membantu dalam memecahkan metode pembelajaran dan penguasaan konsep-konsep IPS yang dilakukan secara terprogram dan tidak sporadis, dan (c) perlu dilakukan penulisan kembali materi-materi IPS yang khusus diperuntukkan bagi guruguru IPS SMP. Karena umumnya guru-guru IPS SMP kesulitan untuk mempelajari secara mandiri konsep Sejarah, Geografi, Sosiologi, Ekonomi yang ada pada buku-buku SMP, SMU, dan PT.Selain itu adanya miskonsepsi materi sosiologi dalam buku-buku yang dipergunakan guru sebagai buku pegangan dalam proses belajar mengajar. Miskonsepsi pada buku akan menimbulkan dampak negatif bagi para pengguna (guru dan siswa). Dalam hal ini pihak sekolah terutama guru harus sangat selektif dalam memilih buku yang digunakan dalam proses belajar mengajar (PBM). Kemampuan guru untuk menyeleksi buku berkaitan langsung dengan kompetensi guru dalam penguasaan materi pelajaran.Hal ini tidaklah mudah karena seorang guru harus menguasai seluruh materi yang diajarkan.

Adanya pengabdian masyarakat ini, guru akan diajak melakukan diskusi untuk pendalaman konsep materi terutama Geografi, menemukan miskonsepsi atau kesalahan konsep materi bentuk muka bumi pada buku IPS SMP yang digunakan dalam pembelajaran, mengintegrasi materi geografi dengan materi IPS lainnya supaya lebih terpadu. Selanjutntya akan dilakukan tutorial untuk mengoreksi kesalahan-kesalahan konsep yang ditemukan.

Bila dikaji secara teoritis, Pendidikan pada hakikatnya adalah proses penyiapan siswa melalui serangkaian kegiatan agar diperoleh hasil seperti yang diinginkan. Dalam pendidikan inputnya adalah siswa dengan segala karakteristik yang dimilikinya, misalnya bakat, minat, dan sikap yang sangat beragam. Proses adalah semua program yang dikembangkan baik yang sifatnya kurikuler maupun non kurikuler, dalam rangka pencapaian tujuan, output yang dimaksudkan adalah kualitas utuh lulusan.

Inti pendidikan sesungguhnya ada dalam proses belajar mengajar, program peningkatan kualitas pendidikan hendaknya dimulai dari peningkatan kualitas pembelajaran, termasuk didalamnya pendalaman materi. Oleh karena itu beberapa penelitian yang telah dilakukan mengungkapkan bahwa usaha-usaha untuk peningkatan kualitas pendidikan tidak akan berarti banyak apabila tidak diiringi dengan peningkatan kualitas proses pembelajaran (Cooper, 1994). Hal ini mengisyrakatkan bahwa program-program peningkatan kualitas pendidikan harus lebih diarahkan pada hal-hal yang berkaitan langsung dengan proses pembelajaran seperti pengadaan media pembelajaran, buku ajar, peningkatan kemampuan guru, dan pendalaman materi. 
Inservice Guru MGMP IPS SMP Kabupaten Blitar...

Salah satu faktor penting dalam peningkatan kualitas pembelajaran adalah kualitas guru. Guru merupakan ujung tombak pendidikan. Sebaik apapun fasilitas dan program yang tersedia, tidak akan memberikan hasil yang baik apabila guruguru yang ada tidak berkualitas. Karena itulah diperlukan usaha-usaha yang terusmenerus dan komprehensif untuk meningkatkan kualitas dan kompetensi guru terutama kompetensi profesional karena komptensi ini berhubungan langsung dengan kinerja yang ditampilkan. Beberapa kemampuan yang berhubungan dengan komptensi sesuai dengan Permen No 16 Tahun 2007 tentang Kompetensi Guru antara lain adalah (1) seorang guru dituntut untuk menguasai materi, struktur, konsep, dan pola pikir keilmuan yang mendukung mata pelajaran, (2) menguasai $\mathrm{KI}$ dan KD, (3) mengembangkan materi pembelajaran secara kreatif, dan (4) mengembangkan keprofesionalan secara berkelanjutan dengan melakukan tindakan reflektif, dan memanfaatlkan TIK untuk mengembangkan diri.

Sebagai sebuah profesi, sebagaimana halnya profesi yang lain, guru memang dituntut untuk senantiasa meningkatkan kemampuan profesionalnya dengan mengikuti program-program peningkatan profesionalisme karena profesionalisme bukan ditandai dengan penguasaan pengetahuan dan keterampilan profesional, namun juga adanya mekanisme untuk meningkatkan pengetahuan dan keterampilan tersebut, serta keinginan untuk senantiasa meningkatkan diri (Stigler \& Hibert, 1999). Program peningkatan profesionalisme guru tentunya juga harus memperhatikan karakterisitik program peningkatan profesionalisme seperti halnya yang berlalu pada profesi yang lain.

Seorang guru dituntut memiliki lima hal untuk menjadi profesional (Susilowati, 2010) yaitu: (1) mempunyai komitmen pada siswa dan proses belajarnya, (2) menguasai secara mendalam bahan/materi pelajaran yang

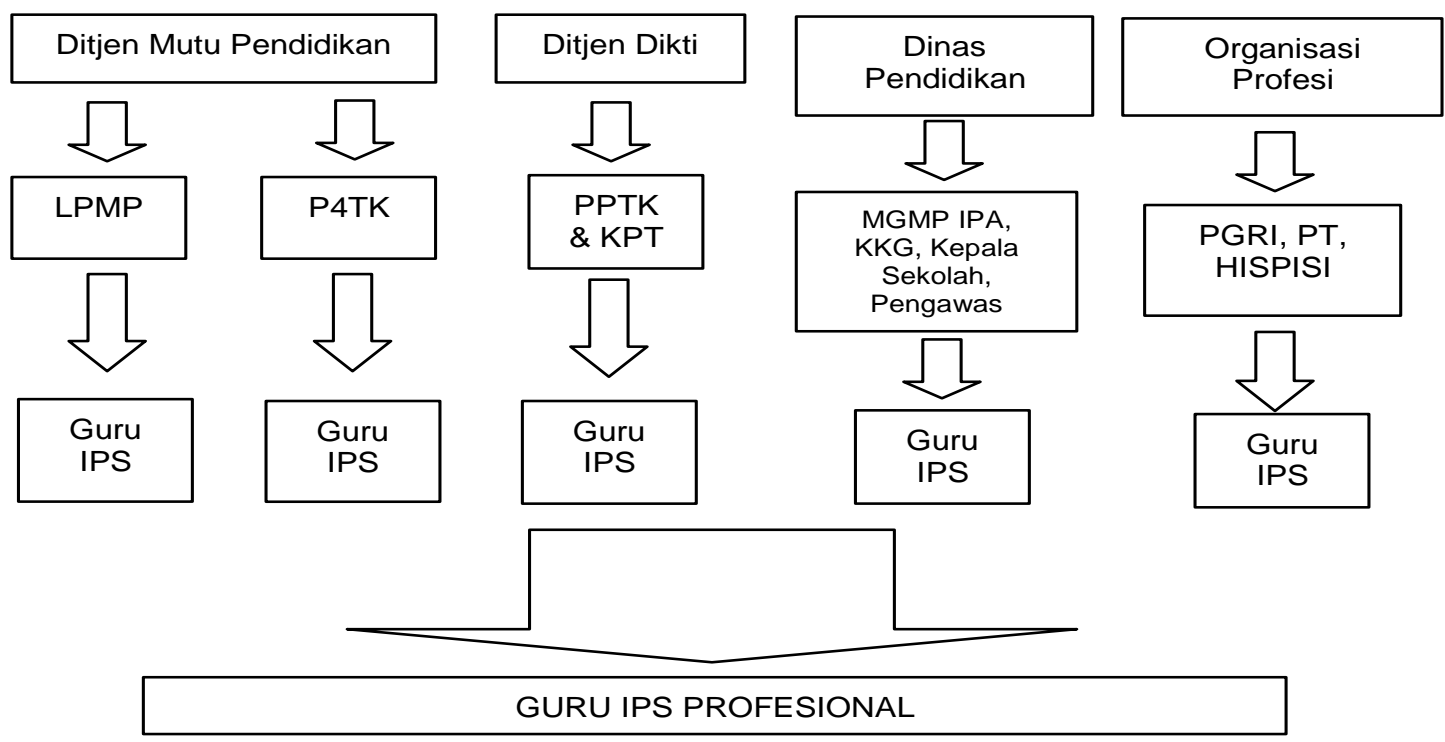

Gambar 1. Komponen Pembina Profesional Guru IPS 
diajarakannya serta cara mengajarkannya kepada siswa, (3) memantau hasil belajar siswa dengan berbagai cara evaluasi, (4) berifikir sistematis tentang apa yang dilakukannya dan belajar dari pengalaman, dan (5) bagian dari masyarakat belajar dalam lingkgan profesinya.

Pembinaan profesionalisme guru di Indonesia dilaksanakan oleh berbagai pihak, mulai dari pembinaan tingkat pusat (Depdiknas), pemerintahan daerah (Dinas), dan tingkatan sekolah. Selain unsur yang berasal dari kelembagaan pemerintah, terdapat pula pembinaan yang dilakukan oleh organisasi profesi seperti HISPISI, PGRI maupun pihak lain misalnya perguruan tinggi. Semua pihak tersebut pada dasarnya ikut berperan serta dalam pembinaan profesionalisme guru, secara diagram dapat digambarkan pada Gambar 1.

Pembinaan profesioalisme guru pada tingkat sekolah dilakukan oleh kepala sekolah dan MGMP sekolah, yang dalam pelaksnaannya dilakukan dalam bentuk pertemuan periodik untuk mendiskusikan peningkatan kualitas pembelajaran. Kepala sekolah melakukan pembinaan profesional secara internal dalam bentuk supervisi akademis dan non akademis kepada para guru. Pembinaan yang berasal dari pihak lain dilakukan dalam berbagai bentuk, baik itu seminar, lokakarya, dan penataran.

\section{METODE PELAKSANAAN}

\section{Metode Penerapan Pengabdian}

Kegiatan ini dilaksanakan dengan cara:

1) Informasi, tanya jawab, dan diskusi, dalam pelatihan penguasaan materi ini diawali dengan penyampaian informasi yang berkaitan dengan mata pelajaran IPS materi Peta NKRI kemudian dilanjutkan dengan tanya jawab dan diskusi untuk menemukan kesalahan konsep yang sering dijumpai guru; 2) Tutorial, kegiatan tutorial untuk mengoreksi atau meluruskan kesalahankesalahan konsep dari hasil identifikasi bersama peserta dan membimbing guru-guru untuk memahami konsep materi Peta NKRI; 3) Evaluasi hasil kegiatan, evaluasi kegiatan dilaksanakan pada awal kegiatan, pada saat pelatihan, dan setelah pelatihan. Evaluasi hasil kegiatan dilakukan untuk mengetahui tingkat keberhasilan pelatihan secara keseluruhan.

\section{Kerangka Pemecahan Masalah}

Kerangka pemecahan masalah yang diusulkan adalah memberikan penyuluhan yang efektif untuk menambah, memperluas, dan memperkaya wawasan tentang Geografi dan meluruskan miskonsepsi materi Peta NKRI yang kurang tepat.

\section{Rancangan Evaluasi}

Kriteria rancangan evaluasi mulai dari kesiapan materi pelatihan dengan indikator semua materi pelatihan telah tersedia, kemudian penguasaan terhadap materi ajar dengan indikator peserta mampu menjawab soal-soal latihan yang diberikan dan angket untuk mengetahui tingkat keberhasilan kegiatan pengabdian ini. Instrumen yang digunakan untuk menilai keberhasilan dalam kegiatan ini adalah: 1) Guru dapat menemukan adanya miskonsepsi materi Peta NKRI; 2) Guru mengetahui konsep yang benar; 3) Untuk monitoring, instrumen yang digunakan adalah angket tanggapan guru 
Inservice Guru MGMP IPS SMP Kabupaten Blitar...

dan angket untuk mengetahui tingkat keberhasilan kegiatan pengabdian.

\section{HASIL KEGIATAN}

Tugas guru sesuai dengan Keputusan MENPAN Nomor 84/1993 dan Keputusan bersama MENDIKBUD dan Kepala BAKN Nomor 0433/P/1993 dan Nomor 25 Tahun 1993, selain berkaitan dengan proses belajar mengajar atau bimbingan, juga berkaitan dengan kegiatan pengembangan profesi guna menunjang peningkatan profesionalisme guru dalam mendidik dan mengajar. Seluruh unsur tersebut selain dapat meningkatkan profesionalisme guru, juga akan berdampak diperolehnya angka kredit, yang dapat dipergunakan untuk memenuhi persyaratan kenaikan pangkat/golongan/jabatan.

Kegiatan pengembangan profesi dapat berupa: mengikuti kegiatan-kegiatan temu ilmiah terutama dalam bidang pendidikan, melaksanakan kegiatan karya tulis atau karya ilmiah di bidang pendidikan, menemukan teknologi tepat guna di bidang pendidikan, membuat alat peraga atau alat bimbingan belajar, dan menciptakan karya seni. Di antara kegiatan-kegiatan tersebut, kegiatan temu ilmiah dipandang penting untuk dilaksanakan oleh guru, karena melalui kegiatan temu ilmiah ini guru dapat dengan mudah dan lebih leluasa mengembangkan peformanya.

Sesuai dengan Permen No 16 Tahun 2007 tentang Kompetensi Guru, terutama tentang kompetensi profesional dijelaskan bahwa seorang guru dituntut untuk menguasai materi, struktur, konsep, dan pola pikir keilmuan yang mendukung mata pelajaran; menguasai $\mathrm{KI}$ dan $\mathrm{KD}$, mengembangkan materi pembelajaran secara kreatif; mengembangkan keprofesionalan secara berkelanjutan dengan melakukan tindakan reflektif, dan memanfaatkan TIK untuk mengembangkan diri. Dengan demikian, seorang guru IPS harus menguasai seluruh materi yang diajarkan.

Berbicara tentang materi di matapelajaran IPS khususnya tentang peta NKRI, guru-guru menjelaskan jika mengalami kesulitan dalam menyampaikan materi ini. Hal ini memang tidak bisa dipungkiri, mengingat peta NKRI mengalami perubahan yang cukup signifikan. Dengan adanya perubahan ini guru-guru tidak terlalu update dan paham akan perubahan yang terjadi. Hal ini tentunya berdampak pada terganggunya penyampaian materi dan terjadinya miskonsepsi oleh guru maupun siswanya. Oleh sebab itulah perlu pendalaman materi dan penguatan terhadap materi peta NKRI.

Kegiatan diawali penyampaian materi peta NKRI yang meliputi tentang sejarah wilayah Indonesia (Nusantara), kenampakan fisik wilayah Indonesia sebelum dan sesudah perubahan, serta faktor yang melatar belakangi perubahan peta NKRI. Di topik sejarah wilayah Indonesia, pemateri menekankan 3 wilayah Nusantara yaitu: Negara Agung yang merupakan daerah sekeliling ibu kota kerajaan tempat raja memerintah; Mancanegara, merupakan daerah-daerah di Pulau Jawa dan sekitarnya yang budayanya masih mirip dengan Negara Agung, tetapi sudah berada di "daerah perbatasan"; Nusantara, yang berarti "pulau 


\section{Nyoman Ruja \& Neni Wahyuningtyas}

lain" (di luar Jawa) merupakan daerah di luar pengaruh budaya Jawa tetapi masih diklaim sebagai daerah taklukan: para penguasanya harus membayar upeti. Terkait topik kenampakan fisik wilayah Indonesia, pemateri menunjukkan citra wilayah Indonesia dan menjabarkan detail wilayah yang mengalami perubahan. lima perubahan yang terjadi yaitu: 1) Perbedaan batas laut teritorial terjadi pada perbatasan antara Indonesia, Singapura dan Malaysia tepatnya di Selat Riau. Pada peta sebelumnya tidak ada zona perairan yaitu South Ledge dan Pedra Branca, untuk peta sekarang diberikan zona perairan. Pedra Branca sendiri milik Singapura, sedangkan South Ledge masih negoisasi antara Singapura dan Malaysia. Kedua wilayah itu diberikan alokasi wilayah selebar 500 meter; 2) Perbatasan antara Indonesia dan Filipina di Laut Sulawesi, jika sebelumnya ditandai dengan garis putusputus atau masih klaim. Dalam perubahan ini sudah resmi menjadi wilayah Indonesia karena perjanjian ZTE antara Indonesia dengan Filipina sudah menghasilkan kesepakatan bahkan sudah ratifikasi dengan UU nomor 4 tahun 2017; 3) Batas dengan Palau, di peta sebelumnya batas wilayah masih melengkung dan diberi garis lurus untuk pulai milik Palau. Sekarang menjadi ditarik garis lurus dan ditutup sehingga menekan sampai sekitar 100 mil. Karena batas ZTE (Zona Tangkap Eksklusif) menjadi perairan Indonesia, dua pulau sebelumnya yaitu Karang Helen dan Pulau Tobi diberi ruang 12 nautical mile (zona perairan); 3) Update atau perubahan penamaan laut, khususnya zona bagian utara Laut Natuna yang kini diberi nama Laut Natuna Utara. Sebelumnya, Laut Natuna hanya berada di bagian dalam garis laut teritorial dan laut kepulauan saja. Hal ini dilakukan mengingat sebelumnya sudah ada kegiatan migas yang menggunakan nama itu, sehingga diharapkan nantinya ada kesamaan penamaan untuk kawasan tersebut; 4) Selat Malaka wilayah Indonesia, juga terjadi beberapa perubahan dari sisi klaim Indonesia. Jika sebelumnya ZEE (Zona Ekonomi Eksklusif) antara Indonesia dengan Malaysia belum rampung ditetapkan. Pada peta terbaru, Indonesia mengklaim ZEE lebih maju menekan ke daerah Malaysia.

Perubahan-perubahan wilayah Indonesia tersebut di atas dilatarbelakangi oleh: 1) adanya perjanjian perbatasan laut teritorial yang sudah berlaku antara Indonesia dan Singapura pada sisi barat dan timur. Selain itu, ada perjanjian batas ZEE (Zona Ekonomi Eksklusif) Indonesia-Filipina yang telah disepakati dan diratifikasi; 2) adanya keputusan arbitrase Filipina-China. Keputusan tersebut memberikan yurisprudensi hukum internasional. Yurisprudensi hukum internasional menyebutkan bahwa pulau yang kecil atau karang yang kecil yang ada di tengah laut yang tidak bisa menyokong kehidupan manusia tidak memiliki hak ZEE 200 mil laut dan landas kontinen. Oleh karena itu, ada beberapa pulau kecil milik negara tetangga kita yang hanya diberikan batas 12 mil laut; 3) ada dampak pada perubahan nama Laut Natuna menjadi Laut Natuna Utara. Hal ini dilandaskan kontinen di kawasan tersebut sejak 1970-an; dan 4) pemerintah ingin 
mempertegas klaim di Selat Malaka dengan melakukan simplifikasi klaim garis batas untuk mempermudah penegakan hukum.

Kegiatan selanjutnya membahas tentang kenampakan fisik wilayah Indonesia sebelum dan sesudah perubahan. Hal ini disebabkan karena mereka belum pernah memperoleh informasi sebelumnya terkait penjelasan detail perubahan dan wujud citra wilayah yang mengalami perubahan. Secara garis besar inti dari pertanyaan para peserta adalah keuntungan jangka panjang apa yang didapat Indonesia dari perubahan tersebut? Jika tidak ada citra seperti yang disajikan oleh pemateri, bagaimana agar memudahkan guru dalam menjelaskan perubahan ini kepada siswa? (supaya lebih konkrit pemahamannya).

Tahap selanjutnya yaitu tutorial dengan memanfaatkan citra. Kegiatan tutorial untuk mengoreksi atau meluruskan kesalahankesalahan konsep dari hasil identifikasi bersama peserta dan membimbing guru-guru untuk memahami konsep materi Peta NKRI. Sebagai tahap akhir kegiatan yaitu evaluasi untuk melihat penguasaan terhadap materi dari kegiatan pengabdian ini, peserta diberikan soal-soal latihan.

\section{KESIMPULAN}

Guru-guru IPS mengalami kesulitan dalam mempelajari konsep ilmu-ilmu sosial secara mandiri. Selain itu tidak jarang ditemukan pemahaman konsep yang keliru pada materi sosiologi. Hal ini berdampak negatif baik bagi siswa maupun guru itu sendiri. Menindak lanjuti permasalahan tersebut maka dibuat kegiatan pengabdian kepada masyarakat. Kesimpulan yang dapat ditarik dari pelaksanaan pengabdian kepada masyarakat ini yaitu melalui pengabdian ini telah meningkatkan motivasi dan pemahaman guru-guru matapelajaran IPS yang tergabung dalam MGMP IPS di Kabupaten Blitar terutama tentang materi Geografi (peta NKRI). Keberlanjutan untuk meningkatkan pemahaman dan kemampuan guru dalam manunjang kompetensinya perlunya memberi kesempatan yang seluasluasnya untuk guru dalam mengembangkan ketrampilan professional melalui workshop dan pelatihan, dan kerjasama secara periodik antara sekolah dengan perguruan tinggi dalam mengembangkan kompetensi guru, sehingga pembimbingan yang dilakukan oleh perguruan tinggi menjadi intensif, efektif dan efisien.

\section{DAFTAR PUSTAKA}

Cooper, B.S, dkk. 1994. Making Money Matter in education: A Micro-Finacial Model for Determining School-Level Allocations, Efficiecy, and Productivity. Journal of Education Finance 20: 66-87 Ibrohim, 2000. Miskonsepsi IPA-Biologi di Kalangan Guru Sekolah Dasar. Proceeding national Science Education Seminar on The Problem of Mathematics and Science Education and Alternatives to Solve the Problems. February 23 , 2000. Malang: FPMIPA, State University of Malang (UM).

Susilowati, E. Sistem Pembinaan Profesional Guru IPA. (Online), wwwp4tkipa.org/banner/artikel/eneng, diakses tanggal 1 Maret 2018.

Peraturan menteri Pendidikan Nasional Republik Indonesia Nomor 16 Tahun 2007 tentang Standar Kualifikasi Akademik dan Kompetensi Guru.Jakarta.

Undang-Undang Nomor 14 Tahun 2015 tentang Guru dan Dosen. . 2013. Kerangka Dasar dan Struktur Kurikulum.Jakarta: Kementerian Pendidikan dan Kebudayaan. 